| Araştırma Makalesi / Research Article |

\title{
Üniversite Öğrencilerinde Kendini Sabotajın Yordayıcısı Olarak Cinsiyet, Yaş ve Farklı Mükemmeliyetçilik Tarzları ${ }^{1}$
}

\section{Gender, Age and Different Perfectionist Styles as Predictors of Self-Handicapping Among University Students}

\section{Göksel Özlü², Nursel Topkaya ${ }^{3}$}

\begin{tabular}{l} 
Anahtar Kelimeler \\
cinsiyet \\
olumlu \\
mükemmeliyetçilik \\
olumsuz \\
mükemmeliyetçilik \\
üniversite öğrencileri \\
yaş \\
\hline Keywords \\
age \\
gender \\
negative perfectionism \\
positive perfectionism \\
university students \\
\hline Başvuru Tarihi/Received \\
23.04 .2019 \\
Kabul Tarihi /Accepted \\
12.04 .2020 \\
\hline
\end{tabular}

\begin{abstract}
Öz
Bu araştırmanın amacı üniversite öğrencilerinde cinsiyet, yaş ve mükemmeliyetçiliğin farklı boyutlarının (olumlu mükemmeliyetçilik, olumsuz mükemmeliyetçilik, düzen) kendini sabotajla ilişkisinin incelenmesidir. Bu amaç doğrultusunda, araştırmanın katılımcılarını oranlı küme örnekleme yoluyla seçilen 598 öğrenci oluşturmuştur. Katılımcılar, Kişisel Bilgi Formu, Olumlu-Olumsuz Mükemmeliyetçilik Ölçeği ve Kendini Sabotaj Ölçeğini cevaplamıştır. Araştırma sonucunda üniversite öğrencilerinin olumlu mükemmeliyetçilik düzeyinin, mükemmeliyetçiliğin düzen boyutunun ve yaşın kendini sabotajı negatif yönde; olumsuz mükemmeliyetçilik düzeyinin ise kendini sabotajı pozitif yönde anlamlı bir şekilde yordadığı bulunmuştur. Ancak, cinsiyetin kendini sabotajın anlamlı bir yordayıcısı olmadığı ortaya çıkmıştır. İlerleyen çalışmalarda kendini sabotaj ve mükemmeliyetçiliğin farklı boyutları arasındaki ilişkide hangi değişkenlerin aracı rolü olduğu araştırılabilir.
\end{abstract}

\section{Abstract}

The aim of this study was to investigate the relationship between gender, age, different dimensions of perfectionism (positive perfectionism, negative perfectionism, order), and self-sabotage in university students. For this purpose, the participants of the study consisted of 598 students selected through proportional cluster sampling. The participants answered the Personal Information Form, Positive-Negative Perfectionism Scale and Self-Sabotage Scale. As a result of the study, the positive and the order subscale scores of perfectionism and age predicted negatively self-sabotage while, negative perfectionism predicted self-sabotage positively. However, the results revealed that sex was not a significant predictor of self-sabotage. In future studies, it can be investigated which variables act as mediators in the relationship between different dimensions of perfectionism and self-sabotage.

\footnotetext{
${ }^{1}$ Bu araştırma, Doç. Dr. Nursel Topkaya danışmanlığında Göksel Özlü tarafından OMü Rehberlik ve Psikolojik Danışma Yüksek Lisans Programında hazırlanan yüksek lisans tezinin özetidir.

${ }^{2}$ Beykoz Rehberlik ve Araştırma Merkezi, İstanbul, TÜRKiYE; https://orcid.org/0000-0002-3169-7707

${ }^{3}$ Sorumlu Yazar, Ondokuz Mayıs Üniversitesi, Eğitim Fakültesi, Eğitim Bilimleri Bölümü, Samsun, TÜRKiYE; https://orcid.org/0000-0002-8469-9140
} 
Extended Abstract

\section{Introduction}

Despite numerous researches on self-sabotage and gender, different results have been found in both national and international studies. Especially contradictory findings in the studies carried out in Turkey were determined. This research can help to determine the relationship between gender and self-sabotage in Turkish university students and to explain these differences in the field. In the literature, there is a limited number of studies investigating the relationship between self-sabotage and age. Only one study (Litvinova, Balarabe ve Mohammed, 2015) was found in which the relationship between age and self-sabotage was examined in university students. In the study, no relation was found between age and self-sabotage (Litvinova et al.). Other studies including the sabotage and age variables (Greaven, Samptor, Thompanson, \& Zuroff, 2000; Leondari \& Gonida, 2007) were conducted with primary, secondary and high school students. This research may help to contribute to the literature by examining the relationship between self-sabotage and age in the university students. The research studies also examining the relationship between age and self-sabotage in Turkey conducted with the working individuals (Coşar, 2012; Zafer, 2016). As a result of both studies, it was found that there was no relationship between age and self-sabotage. In the studies conducted on the self-sabotage tendencies of Turkish university students, no studies that examined the relationship between age and self-sabotage were reached. The aim of this study was to investigate the relationship between gender, age, and different dimensions of perfectionism with self-sabotage behaviors in Turkish university students.

\section{Method}

This research was carried out using a cross-sectional research design. The population of the study consists of 6390 undergraduate students studying at a university in the Middle Black Sea region. The proportional cluster sampling method was used to determine the size of the sample. $67 \%$ of the participants were female $(n=401)$ and $33 \%$ were male $(n=197) .9 .9 \%$ of the participants were attending to German Language Education $(n=60), 7.9 \%$ were English Language Education ( $n=48)$, 5.9\% were Computer and Instructional Technology Education ( $n=36), 2.5 \%$ Biology Education ( $n=15)$, 2.5\% Physics Education ( $n=15), 8.4 \%$ Guidance and Psychological Counseling $(n=51), 3.3 \%$ Music Education ( $n=20)$, 3.6\% Painting Education ( $n=22)$, 12\% Elementary Mathematics Education ( $n=73), 7.1 \%$ Primary Education $(n=43), 8.6 \%$ Social Studies Education ( $n=52)$, 6.6\% Science Education ( $n=40), 12.7 \%$ Special Education $(n=77), 6.1 \%$ Turkish Teaching Education $(n=37)$ and $2.8 \%$ Secondary Mathematics Education ( $n=17)$. The age range of the students participating in the study ranged from 18 to 26 , with a mean age of 21.24 years. (SD=1.47). Personal Information Form, Self-Sabotage Scale (Jones \& Rhodewalt, 1982), and Positive-Negative Perfectionism Scale (Slaney \& Ashby, 1996) were used. Data were collected in the spring term of 2015-2016 academic year. Before the data collection, measurement tools were prepared. Before the application, students were voluntarily taken into the study and informed about how to fill the measurement tools. The application was completed in a single session in approximately 15 minutes. The analysis of the data was performed through the SPSS 23 statistical analysis program for the social sciences. Initial analyzes were performed before the main analyzes.

\section{Findings}

Multiple regression analyzes were conducted in order to determine to what extent sub-scales of perfectionism, namely positive perfectionism, negative perfectionism, and order scores, and also gender and age variables predict self-sabotage scores. In the multiple regression analysis, it was found that the model predicted self-sabotage scores $\left(F(5,592)=67.12, p<.001, R=.60, R^{2}=.36, R^{2}\right.$ adj $\left.=.36\right)$. This model has a high impact size. Positive perfectionism $(\beta=-.30, t=-7.56, p<.001)$, and order $(\beta=-.16, t=-4.18, p<.001)$ sub-scales of perfectionism scale negatively predicted the self-sabotage scores. The increase in age $(\beta=-.07, t=-2.11, p<.05)$ also negatively predicted self-sabotage scores. On the other hand, negative perfectionism $(\beta=.53, t=16.56, p<.001)$ positively predicts self-sabotage scores. Finally, the results showed that gender $(\beta=.03, t=.96, p>.05)$ did not significantly predict self-sabotage scores.

\section{Discussion}

In this study, the predictive role of the positive and negative perfectionism and order sub-scales of perfectionism scale, gender, and age of the self-sabotage were investigated. As a result of the study, positive perfectionism was found to be negatively related to self-sabotage behavior. Although, in the literature, no research study was found examining the relations between positive perfectionism and self-sabotage, research findings support the theoretical explanations. Another result of the study is that negative perfectionism is a positive predictor of self-sabotage behavior. There are research results in the literature that support this research finding. The results showed that the order sub-scale of perfectionism is a negative predictor of self-sabotage. Moreover, the result of the study revealed that gender was not a significant predictor of self-sabotage level of university students. There are researches in the literature that support this result (Elmas \& Akfırat 2015; Kalyon, Dadandı, \& Yazıcı, 2016; Kinnon \& Murray, 2007; Sarıçalı, 2014). As a result of the research, it was found that the increase in age is a negative predictor of self-sabotage. This result of the study was consistent with another research in the field. As a result, it was determined that positive perfectionism and increase in age was a negative predictor of self-sabotage and negative perfectionism was a positive predictor of self-sabotage. In addition, the order subscale of perfectionism was a negative predictor of self-sabotage, whereas gender was not a significant predictor of selfsabotage. In designing psychoeducation programs that aim to reduce self-sabotage behavior, researchers and practitioners may focus on the negative perfectionism and order dimensions of perfectionism to increase the effectiveness of the programs and they may consider the development level of the participants. 
GiRiş

İnsanlar sorumlu oldukları görevde nasıl başarılı olacaklarına dair birçok yöntemle ilgili bilgi sahibidir. Bunun yanında bireysel hedeflerini gerçekleştirmek için yardım alabileceği uzmanlar da bulunmaktadır. Özellikle öğrencilerin başarması gereken sınavlar karşısında nasıl çalışması, çalışmaya ne kadar zaman ayırması gerektiği konusunda fikirleri bulunmakla birlikte öğretmenlerinden, okul psikolojik danışmanlarından veya akranlarından başarılı bir performans sergilemenin yolu ve yöntemiyle ilgili destek alabilmektedir. Ancak başarı için gereken şartlar bilinmesine ve bu konuda destek sağlayacak kişilerin ve kurumların bulunmasına rağmen insanlar erteleme, yetersiz çalışma, okuldan uzaklaşma, yardım istememe, telefon, internet ve madde bağımlıl̆ğ gibi performans engelleyici davranışlara yönelmektedir. Insanların, başarılı olmak için neler yapması gerektiğini bilmesine rağmen neden performansını engelleyici davranışlara başvurduğu konusunda çeşitli araştırmalar bulunmaktadır.

İnsanlar herhangi bir performans öncesinde kendisine belirli bir standart veya hedef belirleyebilir. Sergilediği performans sonucunda yeterlilikleri veya yetersizlikleriyle ilgili bilgi edinebilir. Standartlara ulaşamamak, yetersizlikleri hakkında bilgi sahibi olmak bazı insanlar için kabul edilmesi güç durumlardan biri olabilir. Bu durumda bazı bireyler yetersizliğini gizlemek veya yeterlilik algısını korumak için performans ortamından kaçınabilir veya gerçek performansının ortaya çıkmasını engelleyecek bir davranış ortamı oluşturabilir.

İnsanlar, yeterlilik algılarını korumak ve yetersizlik duygularıyla baş edebilmek için kendini sabotaj davranışlarına da başvurabilir. Jones ve Berglas (1978) kendini sabotaj kavramını bireyin benlik değerini ve yeterlilik algısını koruması için başarısızığı dışsallaştırıp, başarıyı ise içselleştirme imkânı sağlayacak bir davranışın veya performans ortamının birey tarafından seçilmesi olarak tanımlamaktadır. Bu tanıma göre kendini sabotaj, bireylerin performans öncesinde bilinçli olarak performansını engelleme ve performans sonrasında olası bir başarıyı benliğiyle ilişkilendirme, başarısızlığı ise dışsal faktörlere yükleme stratejisidir. Bireyler, görev öncesinde performansını engelleyen etmenler yarattığında veya bulduğunda görev sonrası oluşabilecek başarısızlığın nedenini bu etmenlere yükleyecek, yetersizlik algısından uzaklaşıp öz-yeterlilik hissini koruyacaktır. Bununla birlikte eğer birey görev sonrasında kendi ürettiği engellere rağmen başarılı olursa olumsuz şartlara rağmen başarılı olduğunu düşünecek, yeterlilik algısı korunacak ve benlik algısı olumlu bir yapıya kavuşacaktır (Jones ve Berglas, 1978). Başka bir ifadeyle, kendini sabotaj kavramında bireyin bir işi başarabilme potansiyeline sahip olmasına rağmen yine de yeteneklerinden şüphe duymasına ve bu şüphe sonucu bireyin herhangi bir görevde yetenekleri hakkında objektif değerlendirme yapılmasını engelleme çabasına vurgu yapılır (Özçetin ve Hiçdurmaz, 2016).

Baumeister (1997) kendini sabotaj davranışına başvuran bireyin yetersiz algılanmaktan kaçındığını belirtmektedir. Bu amaçla kendini sabotaj eğilimi yüksek olan bireyler performansının objektif bir şekilde değerlendirilmesini engellemek için performans öncesinde engeller oluşturarak başarısızlığın gerçek nedeninin tespit edilmesini engeller. Kendini sabotaj davranışının bireyler için bir diğer işlevi de bireylerin her zaman kazanma pozisyonunda olmasını sağlamaktır. Birey herhangi bir iş öncesinde performansını engelleyici etmenler oluşturur ve başarılı olursa, engellere rağmen başarılı olduğunu gösterecek ve başkalarının gözünde yeterlilik duygusunu koruyacaktır. Ancak birey, işinde başarılı olamazsa, başarısızlığın sebebini iş öncesinde oluşturduğu engellere yükleyecek ve başkalarının kendisini yetersiz olarak algılamasını engelleyecektir (Sarıçalı, 2014). Bu açıklamalardan kendini sabotaj davranışının bireylerin öz-yeterlilik hissini korumalarına, öz saygı düzeyini arttırmalarına, olumlu benlik algısı geliştirmelerine ve başkaları tarafından yeteneksiz ve yetersiz algılanmayı engellemelerine yardımcı olmak amacıyla gerçekleştirdiği bir eylem olduğu söylenebilir.

Kendini sabotaj stratejileri davranışsal ve sözel stratejiler olmak üzere iki farklı boyutta incelenmektedir (Leary ve Shepperd, 1986). Davranışsal boyutta olan kendini sabotajda birey, performansını doğrudan engelleyen davranışları sergiler. Örneğin, bireyin herhangi bir işten önce alkol kullanması, sınav öncesinde çalışmak yerine arkadaşlarıyla sinemaya gitmesi, bireyin işlerini ertelemesi gibi eylemler davranışsal boyutta kendini sabotaj stratejilerindendir (Urdan ve Midgley, 2001). Sözel kendini sabotaj stratejileri ise doğrudan performansı engelleyecek davranışlara başvurmak yerine olası başarısızlık durumuna mazeret olabilecek etmenlerin belirli bir eylem öncesinde seçilmesi ve ifade edilmesidir. Sınav öncesinde bireyin aşırı kaygı yaşadığını söylemesi, geçmişte yaşadığı olumsuz olaylardan bahsetmesi, bunalımda olduğunu söylemesi sözel kendini sabotaj stratejisi olarak örneklendirilebilir (Sarıçalı, 2014). Davranışsal kendini sabotaj daha gözle görülür, aktif eylemleri kapsarken; sözel kendini sabotaj göreceli olarak daha pasif eylemleri kapsamaktadır (Hendrix ve Hirt, 2009).

Sözel kendini sabotaj davranışında birey performans öncesinde içinde bulunduğu ortam koşullarının iyi olmadığını ifade ederek olası bir başarısızığı bu olumsuz koşullara bağlama eğilimindedir (Smith, Snyder ve Perkins, 1983). Davranışsal kendini sabotajda ise birey olumsuz koşulları kendisi oluşturur ve başarısızıı sonucunda bu engelleri mazeret olarak kullanma eğilimindedir (Leary ve Shepperd, 1986). Araştırmacılar, kendini sabotajda davranışsal stratejiler, sözel stratejilerden daha riskli ve performans azaltıcı olabileceğini bildirmektedir. Örneğin, bireyin sınav öncesinde yüksek düzeyde kaygı yaşadığını ifade etmesi sınav performansı üzerinde herhangi bir etkisi olmayabilir ancak bireyin sınav öncesi yeterli düzeyde çalışma yapmaması sınavdaki başarısızlık ihtimalini artırır. Salomon’a (1997) göre bazı bireyler kendini sabotaj davranışının türünü belirlemek için görev öncesinde kısa bir kar-zarar analizi gerçekleştirir. Bu analiz sonucunda, eğer başarısızlık ihtimali yüksek ise birey davranışsal kendini sabotaj davranışını tercih etme eğilimindedir. Ancak başarısızlık ihtimalinin çok düşük düzeyde var olduğu durumlarda birey sözel kendini sabotaj davranışını tercih etme eğilimindedir. Bu nedenle, başarısızlığa yönelik şüphe düzeyinin kendini sabotaj stratejilerinin türünü belirlemekte önemli bir faktör olduğu söylenebilir (Akt.: Abacı ve Akın, 2011). 
Kendini sabotajla ilgili gerçekleştirilen çalışmalarda kendini sabotaj davranışlarına başvuran bireylerin kişilik özellikleri, hangi sabotaj türünü sıklıkla kullanma eğilimlerinde oldukları ve kendini sabotaj davranışlarına başvurmalarında etkili olan duygusal süreçler sıklıkla ele alınan konulardandır. Örneğin, Jones ve Berglas (1978) öz-saygısı düşük olan bireylerin kendini sabotaja daha fazla başvurabileceğini çünkü öz-saygısı düşük olan bireylerin, öz-saygısı yüksek olan bireylerle karşılaştırıldığında, kendini daha az güvende hissettiğini ve daha fazla başarısızlık beklentisi içinde olduklarını belirtmiştir. Berglas ve Jones (1978) ise kendini sabotaj için bireyin korumaya değer verdiği bir öz-saygısının olmasının gerekli olduğunu; çünkü korumaya değer öz-saygısı olmayan bireyin kendini sabotaja daha az başvurma ihtiyacı içerisinde olacağını belirtmiştir. Want ve Kleitman (2006) ise kendini sabotaja eğilimleri yüksek olan bireylerin ebeveynlerinde koruyucu ve otoriter anne baba tutumları olduğunu, demokratik anne baba tutumunun ise kendini sabotaj davranışını azalttığını tespit ederek kendini sabotaj davranışlarında aile etkisini vurgulamıştır. Bazı araştırmacılar da (Rhodewalt ve Tragakis, 2002) yeteneklerin değişmeyeceğine yönelik inanç besleyenlerin kendini sabotaja daha yatkın olduklarını belirtmiştir. Ayrıca sosyal kaygısı yüksek olanların (Mello-Goldner ve Jackson, 1999) olumsuz benlik algısına sahip olanların ve olumsuz duygulanım yaşayanların (Smederevac vd., 2003), savunmacı kötümserlerin (Elliot ve Church, 2003) daha fazla kendini sabotaj davranışlarına başvurabilecekleri diğer araştırma bulguları arasındadır.

Kendini sabotaj davranışının depresyon ve kaygı (Sahranç, 2011), düşük düzeyde akademik başarı (Hirt, Mccrea ve Kimble, 2000) olumsuz duygulanım (Zuckerman, Kieffer ve Knee, 1998) düşük düzeyde öz saygı (Urdan ve Midgley, 2001), erteleme (Beck, Koons ve Milgrim, 2000) gibi değişkenlerle pozitif yönde ilişki gösterdiği görülmüştür. Aynı zamanda kendini sabotaj davranışının içsel motivasyon ile negatif, dışsal motivasyon ile pozitif yönde ilişki gösterdiği bulunmuştur (Damjan ve Darja, 2011).

Kendini sabotaj davranışıyla ilişkili olabilecek değişkenlerden biri cinsiyettir. Hirt, Mccrea ve Boris'in (2003) kendini sabotajın kadın ve erkekler tarafından nasıl algılandığını incelediği araştırma sonucunda kadınların, kendini sabotaja başvuran bireyleri düşük motivasyonlu, öz kontrolden yoksun ve başarısızıkları için mazerete ihtiyaç duyan bireyler olarak tanımladıklarını tespit etmişlerdir. Berglas ve Jones (1987) gerçekleştirdikleri deneysel araştırmada erkeklerin, kadınlardan daha fazla kendini sabotaja başvurdukları sonucuna ulaşmıştır. Bunun nedeni olarak kadınların başarısızığı şans faktörüne yüklediklerini, erkeklerin ise başarısızlığı yeteneklerine yüklediklerine bağlı olduğunu bildirmiştir. Ayrıca, Mccrea, Hirt ve Milner (2008) kendini sabotajda cinsiyet farklılıklarını açıklarken, kadınların erkeklere göre çabalamaya daha fazla önem verdiklerini, çabalamanın, olumlu benlik algısı oluşturmaktan daha önemli olduğuna inandıklarını ve bu nedenle erkeklere göre daha az kendini sabotaja başvurabileceklerini belirtmiştir. Brown, Park ve Folger (2012), üniversite öğrencileri üzerinde yaptığı araştırmada kadınların bireysel gelişimlerine önem verdiklerini, başarısızlıklar karşısında daha fazla çalışarak eksikliklerini tamamlama yolunu seçtiklerini ve öğrenmeye daha açık olduklarını belirterek kadınların kendini sabotaj eğilimlerinin düşük olduğu sonucuna ulaşmıştır.

Kendini sabotaj ile ilişkili olabilecek bir diğer değişkende yaştır. Ancak, literatür incelendiğinde üniversite öğrencilerinde kendini sabotaj ve yaş arasındaki ilişkinin incelendiğini sınırlı sayıda araştırma mevcuttur (Litvinova, Balarabe ve Mohammed, 2015). Litvinova vd. gerçekleştirdiği araştırma sonucunda yaş ve kendini sabotaj arasında herhangi bir ilişki tespit edilememiştir. Ülkemizde üniversite öğrencilerindeki kendini sabotaj ile yaş arasındaki ilişkiyi inceleyen herhangi bir araştırmaya ulaşılamamıştır ancak kendini sabotaj ile ilişkili olan öz-yeterlilik ve yaş arasındaki ilişkiyi bulgulayan araştırma mevcuttur (Oğuz, 2009). Oğuz, yaşları 18-25 arasında değişen üniversite öğrencileri üzerinde gerçekleştirdiği araştırma sonucunda üniversite öğrencilerinde yaş ile öz-yeterlilik düzeyleri arasında pozitif yönde ilişki olduğu sonucuna ulaşmıştır. Bir başka araştırma Alemdağ (2015) tarafından gerçekleştirilmiş ve 22 yaş üstü üniversite öğrencilerinin 19 yaş altı üniversite öğrencilere göre öz-yeterlilik düzeylerinin yüksek olduğu tespit edilmiştir. Ayrıca Alemdağ, üniversite öğrencileri üzerinde gerçekleştirdiği araştırmasında 21 yaş üstü üniversite öğrencilerinin öğrenme yeteneğinin doğuştan gelen değil eğitim veya deneyimle geliştirilebileceğine yönelik inancının olduğunu 21 yaş altındaki üniversite öğrencilerinin ise öğrenme yeteneğinin doğuştan geldiğine yönelik inancın daha fazla olduğu sonucuna ulaşmıştır. Rhodewalt ve Tragakis (2002) yeteneğin değişmeyeceğine yönelik inancı olanların kendini sabotaj eğilimlerinin yüksek olacağını belirtirken, Pulford, Johnson ve Awaida (2005) öz-yeterliliğin kendini sabotaj düzeyinin negatif bir yordayıcısı olduğu sonucuna ulaşmıştır. Bu araştırma sonuçları dikkate alındığında üniversite öğrencilerinin yaşlarının ilerlemesiyle birlikte özyeterlilik düzeylerinin artması ve öğrenme yeteneğinin çalışmaya bağlı olarak gelişeceği inancının gelişmesi kendini sabotaj eğilimlerini azaltabilir. Bu nedenle, yaş ile kendini sabotaj arasında negatif bir ilişkinin olması beklenebilir.

Kendini sabotajla ilişkili olabilecek değişkenlerden biri de mükemmeliyetçiliktir. Mükemmeliyetçilik kavramı birçok araştırmacı tarafından ele alınmış ve bu kavram üzerine farklı tanımlar yapılmıştır. Flett ve Hewitt (2002) gerçekçi olmayan yüksek standartlar belirleme, başarısızlıklara odaklanma ve benliğe zarar veren değerlendirmeler yapma ile iki uçlu düşünmenin olduğu kişilik yapısını mükemmeliyetçilik olarak tanımlar. Hollender (1965), mükemmeliyetçilik kavramı üzerine ilk çalışanlardan biri olarak mükemmeliyetçiliği kusursuz davranış ve başarı yoluyla çevrenin onayını alma çabası olarak tanımlar. Burns (1980) mükemmeliyetçi kişileri kendine gerçek üstü yüksek standartlar belirleyen, bu standartlara katı biçimde bağlanan ve kendi değerini bu standartlara ulaşma oranına göre değerlendiren kişiler olarak tanımlamaktadır.

Mükemmeliyetçilik kavramını olumsuz bir kişilik özelliği olarak ele alan araştırmacıların yanında bu kavramın olumlu bir kişilik özelliği olabileceği yönünde de açıklamalar bulunmaktadır. Adler'e (1968) göre çoğu insan yaşamın ilk yıllarında ihtiyaçlarının karşılanması için çevresine muhtaç olduğunu ve bu muhtaçlığın bireyde yetersizlik hissine sebep olduğunu belirtir. Birey, yaşamı boyunca yetersizlik hissinden kurtulma çabasını üstünlük duygusu olarak tanımlar. Aynı zamanda insanın gelişmesi için bu çabanın mutlaka bulunması gerektiğini ifade eder (Gençtan, 2002). Adler, mükemmeliyetçilik kavramının üstünlük duygusunun sonucu olduğunu belirtir ve mükemmeliyetçiliğin bireyin gelişimine katkı sağlayabileceğini vurgular (Akt: Kıral, 2012). 
Mükemmeliyetçilik kavramını tek boyutlu olarak değerlendiren araştırmacılar olduğu gibi bu kavramın olumlu-olumsuz olarak iki boyutta değerlendirilebileceğini belirten araştırmacılar da bulunmaktadır. Hamachek (1978) mükemmeliyetçilik kavramını normal ve nevrotik olmak üzere iki boyutta ele alan ilk araştırmacıdır. Roedell (1984) mükemmeliyetçiliği olumlu-olumsuz boyutuyla ele almaktadır. Roedell'e göre olumlu mükemmeliyetçi kişilik özelliği bireyin başarıya ulaşması için motive edici bir güç olabilirken, olumsuz mükemmeliyetçi kişiler başarıya ulaşmada kaygı yaşar ve olası başarısızlık durumunda kendini cezalandırma davranışına yönelir. Hamachek (1978) normal mükemmeliyetçilik kişilik yapısına sahip bireylerin görevler karşında yoğun çaba göstererek standartlarına ulaşmaya çalıştığını ayrıca yetersizliklerinin farkında olduğunu ve bunu kolayca kabullenebildiklerini ifade eder. Normal mükemmeliyetçilik kişilik özelliğine sahip bireylerin esnek düşündüğünü, duygusal anlamda daha güçlü olduğunu belirtir. Nevrotik mükemmeliyetçilik kişilik yapısına sahip bireylerin ise yetersizliklerini kabullenemediklerini, yapabileceklerinin üstünde hedefler belirleyerek benlik saygılarının düşmelerine neden olduklarını, herhangi bir görev öncesinde yoğun kaygı yaşadıklarını belirtir (Altun ve Yazıcı, 2010).

Mükemmeliyetçilik kavramının olumlu-olumsuz boyutuyla ilgili çok sayıda araştırma gerçekleştirilmiştir. Olumsuz mükemmeliyetçilik ile ilgili yapılan araştırmalarda mükemmeliyetçiliğin bu boyutunun düşük öz-saygı (Ashby ve Rice 2002), aşağılık duygusu (Ashby ve Kottman, 1996), obsesif kompulsif, kişilerarası duyarlık, yaygın anksiyete, öfke-düşmanlık, sosyal kaygı (Sapmaz, 2006) ile ilişki gösterdiği görülmüştür. Olumlu mükemmeliyetçilik düzeyinin ise akademik başarı (Altun ve Yazıcı, 2010) ile pozitif yönde ilişki gösterdiği bulunurken, obsesif kompulsif, kişilerarası duyarlık, depresyon, anksiyete, öfke-düşmanlık, sosyal kaygı (Sapmaz, 2006) gibi psikolojik rahatsılıkları içeren belirtilerle negatif yönde anlamlı ilişki gösterdiği bulunmuştur.

Kottman ve Ashby'e (2000) göre olumlu mükemmeliyetçilik kişilik özelliğine sahip bireyler, yüksek standartlara ulaşmak için kaygı yaşamazlar ve standartlarına ulaşamadıklarında çöküntü veya değersizlik hissi yaşamak yerine daha sıkı çalışmak için motive olurlar. Kottman ve Ashby, olumlu mükemmeliyetçilik kişilik özelliğine sahip bireylerin belirlediği yüksek standartlara ulaşmak için yoğun çaba harcadığını ve belirledikleri yüksek standartları performanslarını arttırmak için kullandığını belirtir. Olumsuz mükemmeliyetçilik kişilik özelliğine sahip bireylerin ise yüksek standartlara sahip olmasına rağmen bu standartlara ulaşmak için herhangi bir çaba harcamadığını ifade eder. Ayrıca, Slade ve Owens (1998) olumlu mükemmeliyetçi kişilerin mükemmel olmaktan keyif aldığını, yüksek standartlara erişmek için yoğun endişe yaşamadıklarını, gösterdikleri performansı benliği ile ilişkilendirmediklerini belirtir. Olumlu mükemmeliyetçilik kişilik özelliğindeki bireylerin yüksek standartlarına ulaşmak için çaba harcamaları, görevin sonucunu benlikleriyle ilişkilendirmemeleri kendini sabotaj davranışlarını engelleyen bir faktör olabilir. Bu araştırmada olumlu mükemmeliyetçilik düzeyinin kendini sabotajın negatif bir yordayıcısı olacağı düşünülmektedir. Diğer taraftan olumsuz mükemmeliyetçilik kişilik özelliğine sahip bireyler standartlarına ulaşma konusunda yoğun kaygı yaşarlar ve bu standartlara ulaşamadığında yetersizlik duyguları hissederler. Suddarth ve Slaney (2001) olumsuz mükemmeliyetçilik kişilik özelliğine sahip bireylerin yanlış yapma korkusu ve yetersiz algılanma endişesini sıklıkla yaşadığını belirtir. Olumsuz mükemmeliyetçilik kişilik özelliğine sahip bireylerin yüksek standartlara ulaşamama ihtimalinde meydana gelebilecek yetersiz algılanmaya yönelik endişe, kendini sabotaj davranışlarını motive eden temel faktör olabilir. Yetersizlik duygusuyla baş edebilmek için olumsuz mükemmeliyetçilik kişilik özelliğine sahip bireyler kendini sabotaj davranışlarına başvurabilirler.

Frost, Marten, Lahart ve Rosenblate (1990) mükemmeliyetçi bireylerin düzenli ve tertipli olma çabasında olduklarını belirtmiştir. Her şeyin yerli yerinde olmasına, belli bir sistem içerisinde olmasına, eşyaların tertipli olmasına, yönelik beklenti ve çaba, mükemmeliyetçiliğin düzen boyutuyla ilişkilendirilir. Frost vd. (1990) geliştirdikleri çok boyutlu mükemmeliyetçilik ölçeğinde mükemmeliyetçiliğin düzen boyutunu ölçmeyi hedeflemişlerdir. Bu araştırmacıların geliştirdiği ölçekte düzen boyutu organizasyona aşırı derece önem veren, bulundukları ortamın ve çalıştıkları işin tertipli olmasını isteyen mükemmeliyetçi bireyleri kapsar. Düzen boyutuna Slaney, Rice, Mobley, Trippi ve Ashby (2001) geliştirdikleri ölçekte de yer vermiştir ve bu ölçekte düzen boyutu olumlu mükemmeliyetçilik özelliği olarak değerlendirilmektedir. Ayrıca Slaney vd. olumlu mükemmeliyetçilik kişilik özelliğine sahip bireylerin belirledikleri yüksek standartlara ulaşmak için belirli bir plan ve program dâhilinde hareket ettiklerini dolayısıyla düzenli olmanın mükemmeliyetçiliğin olumlu özelliklerinden olacağını belirtir. Ayrıca, Altun ve Yazıcı (2010) olumlu mükemmeliyetçi kişilik yapısına sahip bireylerin kendilerine yüksek standartlar belirleyip bu standartlara ulaşmak için belli bir düzen ve tertip içinde çalıştığını belirtir. Mükemmeliyetçiliğin düzen boyutu ve kendini sabotaj ilişkisi üzerine herhangi bir araştırmaya ulaşılamamıştır. Yalnızca erteleme eğilimi yüksek olan bireylerin çalışma ortamlarını temizlemek, düzenlemek ve tertipli hale getirmekle zaman kaybettiklerine yönelik bulgular bulunmaktadır (Burka ve Yuen, 2008). Bu doğrultuda kendini sabotaj davranışlarından olan erteleme ile mükemmeliyetçiliğin düzen boyutu ilişkili olabilir. Herhangi bir görev öncesinde birey, düzenli olmaya fazlaca vakit harcayarak çalışmasını erteler, yetersiz egzersiz yapar ve görev sonrasında olası bir başarısızlık durumunda çevresini düzenlemekle meşgul olduğu için başarısız olduğunu ifade edebilir. Bu erteleme modeli, düzenli olmanın kendini sabotaja yol açacağını düşündürebilir. Ancak bu modelde bireyler, düzenli olmak için veya düzene karşı ilgili olduğu için değil, ertelemeyi gerçekleştirme amacıyla tertipli olmaya çalışır ve düzenli olmayı, performansını sabote etmek için bir araç olarak kullanır. Bireylerin performanslarını sabote etmesi için düzenli olması, onların gerçek anlamda mükemmeliyetçiliğe bağlı düzenli olma isteğinden kaynaklı olabilir.

Mükemmeliyetçilik ile kendini sabotaj arasındaki ilişkiyi belirlemek için alanda birçok araştırma yapılmıştır. Ancak kendini sabotaj ve mükemmeliyetçilik arasındaki ilişkiyi inceleyen araştırmalar, mükemmeliyetçiliği genel olarak olumsuz boyutta incelemiştir. Mükemmeliyetçiliğin olumlu boyutu ile kendini sabotaj arasındaki ilişki üzerine gerçekleştirilmiş herhangi bir araştırmaya ulaşılamamıştır. Bu araştırma kendini sabotaj ve olumlu mükemmeliyetçilik arasındaki ilişkiyi belirginleştirmekte yardımcı olabilir. Olumsuz mükemmeliyetçilik ile kendini sabotaj arasındaki ilişkiyi araştıran çalışmalar bulunmakla birlikte bu 
araştırma yurtdışında gerçekleştirilmiştir. Türk örnekleminde kendini sabotaj ve mükemmeliyetçilik arasındaki ilişkiyi inceleyen herhangi bir araştırmaya ulaşılamamıştır. Türk örnekleminde kendini sabotaj ve mükemmeliyetçilik arasındaki ilişkiyi araştıracak olan bu çalışma literatürdeki bu eksikliğin tamamlanmasına yardımcı olabilir.

Kendini sabotaj ve cinsiyet üzerinde çok sayıda araştırma gerçekleştirilmesine rağmen hem yurt içindeki hem de yurt dışındaki araştırmalarda farklı sonuçlara ulaşımıştır. Özellikle Türkiye'de gerçekleştirilen araştırmalarda çelişkili bulgular tespit edilmiştir. Bu araştırma Türk üniversite öğrencilerinde cinsiyet ve kendini sabotaj arasındaki ilişkiyi belirlemek için ve alandaki bu farklılıkları açıklamada yardımcı olabilir. Literatürde kendini sabotaj ve yaş arasındaki ilişkiyi inceleyen sınırlı sayıda araştırma vardır. Üniversite öğrencilerinde yaş ve kendini sabotaj arasındaki ilişkinin incelendiği yalnızca bir araştırmaya (Litvinova vd., 2015) ulaşılmıştır. Bu araştırmada ise yaş ve kendini sabotaj arasında herhangi bir ilişki tespit edilmemiştir. Kendini sabotaj ve yaş değişkenlerini ele alan diğer araştırmalar (Greaven, Samptor, Thompanson ve Zuroff, 2000; Leondari ve Gonida, 2007) ise ilkokul, ortaokul ve lisede öğrenim gören öğrenciler üzerinde gerçekleştirilmiştir. Bu araştırma üniversite öğrencilerinde kendini sabotaj ve yaş arasındaki ilişki düzeyinin incelenerek alanyazınındaki eksikliğin giderilmesine yardımcı olabilir ve bu konuda yapılacak çalışmalara yardımcı olabilir. Ayrıca Türkiye örnekleminde kendini sabotaj ile yaş arasındaki ilişkiyi inceleyen araştırmalar çalışan bireyleri kapsamaktadır (Coşar, 2012; Zafer, 2016). Her iki araştırma sonucunda da yaş ve kendini sabotaj arasında herhangi bir ilişki olmadığı tespit edilmiştir. Türk üniversite öğrencilerinde ise yaş ve kendini sabotaj arasındaki ilişkinin incelendiği herhangi bir çalışmaya ulaşılamamıştır. Bu araştırmanın amacı Türk üniversite öğrencilerinde cinsiyet, yaş ve mükemmeliyetçiliğin farklı boyutlarının kendini sabotaj davranışlarıyla ilişkisini incelemektir.

\section{YÖNTEM}

\section{Evren ve Örneklem}

Bu araştırmada kesitsel bir araştırma deseni kullanılmıştır. Araştırmanın evrenini Orta Karadeniz Bölümündeki bir üniversitenin eğitim fakültesinde öğrenim gören toplam 6390 lisans öğrencisi oluşturmuştur. Örneklemin büyüklüğünün tespitinde oranlı küme örnekleme yöntemi kullanılmıştır. Bu amaçla, ilk olarak evren büyüklüğü bilinen örneklemler için örneklem büyüklüğü hesaplama formülleri kullanılarak gerekli olan minimum örneklem büyüklüğü hesaplanmıştır (Krejcie ve Morgan, 1970). Sosyal bilimlerde sıklıkla .50 evren oranında, \%95 güven aralığında, \%5 hata payı ile ihtiyaç duyulan örneklem büyüklüğü hesaplanmaktadır. Bu çalışmada da aynı oranlar kullanılmış ve gerekli istatistiksel işlemler gerçekleştirildikten sonra ihtiyaç duyulan örneklem büyüklüğü miktarının 362 olduğu bulunmuştur. Olası kayıp veriler ve evrenin daha iyi bir şekilde temsil edilebilmesine imkan sağlamak amacıyla en az 500 katılımcıya ulaşılması amaçlanmıştır. İkinci aşamada, eğitim fakültesindeki on bölümün (Bilgisayar ve Öğretim Teknolojileri Eğitimi Bölümü, Ortaöğretim Fen ve Matematik Alanları Eğitimi Bölümü, Eğitim Bilimleri Bölümü, Güzel Sanatlar Eğitimi Bölümü, Din Kültürü ve Ahlak Bilgisi Öğretmenliği Bölümü, İlköğretim Bölümü, Ortaöğretim Sosyal Alanlar Eğitimi Bölümü, Özel Eğitim Bölümü, Türkçe Eğitimi Bölümü, Yabancı Diller Eğitimi Bölümü) toplam öğrenci sayıları ve evreni temsil etme yüzdesi hesaplanmıştır. Daha sonra oranlı küme örnekleme yöntemiyle belirlenmiş bu yüzdelere göre de örneklem sayıları belirlenmiştir. Katılımcıların \%67'si kadın ( $n=401)$, \%33'ü erkektir ( $n=197)$. Katılımcıların \% 9.9'u Almanca Öğretmenliği ( $n=60)$, \%7.9'u İngilizce Öğretmenliği ( $n=48), \% 5.9^{\prime}$ u Bilgisayar ve Öğretim Teknolojileri Öğretmenliği ( $\left.n=36\right)$, \%2.5'i Biyoloji Öğretmenliği ( $\left.n=15\right)$, \%2.5’i Fizik Öğretmenliği ( $n=15), \% 8.4^{\prime}$ ü Rehberlik ve Psikolojik Danışmanlık ( $\left.n=51\right), \% 3.3^{\prime}$ ü Müzik Öğretmenliği $(n=20), \% 3.6$ 'sı Resim-iş Öğretmenliği ( $n=22), \% 12$ 'si illköğretim Matematik Öğretmenliği ( $n=73)$, \%7.1'i Sınıf Öğretmenliği ( $n=43)$, \%8.6'sı Sosyal Bilgiler Öğretmenliği ( $n=52), \%$ 6.6’sı Fen Bilgisi Öğretmenliği $(n=40), \%$ 12.7'si Zihinsel Engelliler Öğretmenliği $(n=77)$, \% 6.1'i Türkçe Öğretmenliği ( $n=37), \% 2.8$ 'i Ortaöğretim Matematik Öğretmenliği $(n=17)$ bölümlerinde eğitim görmektedirler. Araştırmaya katılan öğrencilerin yaş aralığı 18 ile 26 arasında değişmekte olup, yaş ortalamaları 21.24'tür (S.s=1.47).

\section{Veri Toplama Araçları}

Kişisel Bilgi Formu: Bu form katılımcıların cinsiyeti ve yaşı hakkında bilgi toplamak amacıyla kullanılmıştır.

Kendini Sabotaj Ölçeği: Kendini Sabotaj Ölçeği (KSÖ) Jones ve Rhodewalt (1982) tarafından geliştirilmiş 6’lı derecelendirmeye sahip bir ölçme aracıdır. Ölçeğin Türkçeye uyarlama, geçerlilik ve güvenirliliği çalışmaları Akın (2012) tarafından gerçekleştirilmiştir. KSÖ 25 farklı betimsel ifadeden oluşmaktadır ve katılımcılardan her bir maddede yer alan açıklamaya katılma derecelerini belirtmeleri istenmektedir. Ölçekte yer alan maddeler, çaba harcamama, hastalanma, erteleme, alkol veya ilaç kullanma, uykusuzluk veya duygusal problemler gibi bir dizi kendini sabotaj stratejisini ölçmeyi amaçlamaktadır. Ölçekte yer alan 3, 5, 6, 10, 13, 20, 22 ve 23 maddeler tersten kodlandıktan sonra tüm maddelerin puanları toplanarak kendini sabotaj puanı elde edilebilmektedir. Ölçekten alınabilecek puanlar 25 ile 150 arasında değişmektedir. Ölçekten alınan yüksek puanlar ilgili bireyin sözel ve davranışsal kendini sabotaj eğiliminin yüksek olduğunu göstermektedir. Akın (2012) tarafından ölçeğin Jones ve Rhodewalt (1982) tarafından önerilen tek faktörlü yapıya üniversite öğrencilerinde iyi bir uyum gösterdiği (RMSEA=.037, NFI=.98, CFI=.99, $\mathrm{IFI}=.99, \mathrm{RFI}=.97, \mathrm{GFI}=.97, \mathrm{AGFI}=.94)$ bildirilmiştir. Aynı zamanda, ölçeğin iç tutarlılık katsayısı .90, üç hafta arayla uygulanması sonucu elde edilen test-tekrar test güvenirlik katsayısı ise .94 olarak bulunmuştur. Ölçekten örnek bir madde "Yanlış bir şey yaptığımda ilk tepkim içinde bulunduğum şartları suçlamaktır." şeklindedir. Ölçeğin bu çalışma için hesaplanan Cronbach alpha iç tutarlılık katsayısı .69'dur.

Olumlu-Olumsuz Mükemmeliyetçilik Ölçeği: Olumlu-Olumsuz Mükemmeliyetçilik Ölçeği (OOMÖ), Slaney ve Ashby (1996) tarafından geliştirilmiş, daha sonra Slaney vd. (2001) tarafından revize edilmiştir. Slaney vd. (2001) tarafından revize edilen OOMÖ 
23 madde ve üç alt ölçekten oluşmaktadır. Ölçek, Likert tipinde 1-7 arası değerlendirme ile "1-Tamamen Katılmıyorum”, "2Katılmıyorum", "3-Kısmen Katılmıyorum”, "4-Bir Fikrim Yok", "5-Kısmen katılıyorum”, "6-Katılıyorum”, "7-Tamamen Katılıyorum" cevaplarına karşılık gelecek şekilde özgün formunda olduğu şekilde düzenlenmiştir. Olumlu-Olumsuz Mükemmeliyetçilik ölçeği Yüksek Standartlar, Düzen ve Uyuşmazlık alt boyutlarından oluşmaktadır. Yüksek Standartlar alt ölçeğinden alınabilecek puan 749 arasında, Düzen alt ölçeğinden alınabilecek puan 4-28 arasında, Uyuşmazlık alt ölçeğinden alınabilecek puan 12-84 arasında değişmektedir. Yüksek standartlar alt ölçeğinden alınan puanlar olumlu mükemmeliyetçilik düzeyini; uyuşmazlık alt ölçeğinden alınan puanlar olumsuz mükemmeliyetçilik düzeyini; düzen alt ölçeğinden alınacak puanlar mükemmeliyetçiliğin düzen boyutunu belirlemektedir (Ulu, 2007). Ölçeğin, Türkçeye uyarlama çalışmaları ve üniversite öğrencilerinde geçerliliği ve güvenirliliği Ulu (2007) tarafından gerçekleştirilmiş ve ölçeğin Slaney vd. (2001) tarafından belirtilen üç faktörlü yapıya Türk üniversite öğrencilerinde iyi uyum gösterdiği, iki hafta arayla uygulanması sonucu elde edilen test-tekrar test güvenirliliği ve Cronbach alpa iç tutarlılık katsayısının iyi düzeyde olduğu bildirilmiştir (Ulu, 2007). Ölçeğin bu çalışma için hesaplanan Cronbach alpha iç tutarlılık katsayısı olumlu mükemmeliyetçilik alt boyutu için .81, olumsuz mükemmeliyetçilik için .89 ve düzen alt boyutu için .85 olarak hesaplanmıştır. OOMÖ’nün Standartlar alt ölçeği için örnek madde: “iş̧te veya okuldaki performansımla ilgili standartlarım yüksektir." şeklindedir. Uyuşmazlık alt ölçeği için örnek madde: "Hedeflerime ulaşamadığım için kendimi çoğu zaman engellenmiş hissederim." şeklinde olup, Düzen altı ölçeği için örnek madde: "Derli toplu olmak benim için önemlidir." şeklindedir.

\section{Prosedür}

Veriler 2015-2016 eğitim yılının bahar döneminde toplanmıştır. Veri toplama öncesinde ölçme araçları set haline getirilmiştir. Uygulama öncesinde öğrencilerden izin alınarak araştırmaya gönüllü katılımı sağlanmış ve ölçme araçlarını nasıl dolduracakları konusunda öğrencilere bilgi verilmiştir. Uygulama tek oturumda yaklaşık olarak 15 dakika içinde tamamlanmıştır.

\section{Verilerin Analizi}

Verilerin analizi SPSS 23 sosyal bilimler için istatistiksel analiz programı aracılığıyla gerçekleştirilmiştir. Analizler gerçekleştirilmeden önce başlangıç analizleri gerçekleştirilmiştir. Başlangıç analizlerinde verilerin kullanılacak analizlere hazırlanması ve uygulanacak istatistiksel analizlerin varsayımlarını incelemek amacıyla bir dizi işlem gerçekleştirilmiştir. ilk olarak verilerin doğru olarak girilip girilmediği frekans dağılımları incelenerek kontrol edilmiştir. Yanlış girilen bir veri olmadığı görülmüştür. İkinci aşamada kayıp değerler incelenmiştir. Kayıp değerlerin veri setinde mükemmeliyetçilik ölçeğinde \% 0 ila \%0.2 aralığında, kendini sabotaj ölçeğinde ise \%0 ile \%1.3 arasında değiştiği görülmüştür. Bu kayıp değerlerin veri setinde seçkisiz dağılım gösterip göstermediği, Little’nin (1988) kayıp değerlerin tamamen seçkisiz dağılıp dağılmadığına ilişkin geliştirdiği testle incelenmiş ve verilerin tamamen seçkisiz dağıldığı görülmüştür (Little's $\left.\chi^{2}(906)=962.60, p=.094\right)$. Bu nedenle, ölçme ve değerlendirme uzmanları tarafından veriler tamamen seçkisiz dağıldığında kullanılması önerilen (Enders, 2010; Graham, 2009; Schafer ve Graham, 2002) beklenti-maksimizasyon algoritması kullanılarak kayıp değer atama işlemi gerçekleştirilmiştir. Üçüncü aşamada, tek değişkenli aykırı değerler, dördüncü aşamada, çok değişkenli aykırı değerler incelenmiştir. Kendini sabotaj ölçeğinden bir tek değişkenli aykırı değer ve çok değişkenli bir aykırı değer veri setinden çıkarılmıştır (Tabachnick ve Fidell, 2012). Sonuç olarak analizler 598 katılımcının verileriyle gerçekleştirilmiştir.

Olumlu mükemmeliyetçilik, olumsuz mükemmeliyetçilik, düzen ve kendini sabotaj toplam puanları ve yaş arasındaki ilişkiler Pearson korelasyon katsayısı ve cinsiyetin yukarıda sözü edilen sürekli değişkenlerle ilişkisi nokta çift serili korelasyon katsayısı analizi aracılığıyla incelenmiştir. Olumlu mükemmeliyetçilik, olumsuz mükemmeliyetçilik, düzen, cinsiyet ve yaşın kendini sabotaj puanlarını ne düzeyde yordadığını belirleyebilmek amacıyla ise çoklu regresyon analizi gerçekleştirilmiştir. Pearson korelasyon analizi ve çoklu regresyon analizinden önce normallik, doğrusallık, yeterli örneklem büyüklüğü, hata dağılımlarının normalliği, hata varyanslarının homojenliği (heteroskedasticity), çoklu doğrusallık gibi varsayımları uygun olan analizlerde incelenmiş ve karşılandığı görülmüştür (Tabachnick ve Fidell, 2012). Tüm analizlerde .05 hata payı üst sınır olarak belirlenmiştir.

\section{BULGULAR}

Tablo 1'de değişkenler arasındaki korelasyon katsayıları ve değişkenlerin ortalama ve standart sapma değerleri görülmektedir. Tablo 1'de görüldüğü gibi, cinsiyet, yaş $(r=.14, p<.01)$, olumlu mükemmeliyetçilik $(r=.09, p<.05)$, olumsuz mükemmeliyetçilik $(r=$ $.15, p<.01)$, kendini sabotaj $(r=.10, p<.05)$ ile pozitif yönde ilişkilidir. Ancak cinsiyet, düzen $(r=-.12, p<.01)$ ile negatif yönde düşük düzeyde ilişkilidir. Yaş ise olumlu mükemmeliyetçilik $(r=.14, p<.01)$ ve düzen $(r=.12, p<.01)$ ile pozitif yönde, kendini sabotaj $(r=$ $-.08, p<.05)$ ile negatif yönde düşük düzeyde ilişkilidir. Ancak yaş, olumsuz mükemmeliyetçilik $(r=.08, p>.05)$ ile ilişkili değildir. Olumlu mükemmeliyetçilik ise olumsuz mükemmeliyetçilik $(r=.37, p<.01)$ ve düzen $(r=.45, p<.01)$ ile orta düzeyde pozitif yönde ilişkili olup kendini sabotaj $(r=-.16, p<.05)$ ile düşük düzeyde negatif yönde ilişkilidir. Olumsuz mükemmeliyetçilik ise düzen $(r=$ $.12, p<.01)$ ile düşük düzeyde, kendini sabotaj $(r=.46, p<.01)$ ile de orta düzeyde pozitif yönde ilişkilidir. Son olarak, düzen ile kendini sabotaj $(r=-.24, p<.01)$ arasında düşük düzeyde negatif yönde anlamlı bir ilişki vardır. 
Tablo 1. Değişkenler arasındaki korelasyon katsayıları ve değişkenlerin ortalama ve standart sapma değerleri

\begin{tabular}{|c|c|c|c|c|c|c|}
\hline & 1 & 2 & 3 & 4 & 5 & 6 \\
\hline 1. Cinsiyet & - & & & & & \\
\hline 2. Yaş & $.14^{* *}$ & - & & & & \\
\hline 3. Olumlu & $.09 *$ & $.14^{* *}$ & .81 & & & \\
\hline 4. Olumsuz & $.15^{* *}$ & .08 & $.37^{* *}$ & .89 & & \\
\hline 5.Düzen & $-.12 * *$ & $.12^{* *}$ & $.45^{* *}$ & $.12^{* *}$ & .85 & \\
\hline 6. Kendini Sabotaj & $.10^{*}$ & $-.08 *$ & $-.16 * *$ & $.46^{* *}$ & $-.24 * *$ & .69 \\
\hline Ortalama & 1.33 & 21.24 & 32.78 & 42.57 & 19.76 & 80.31 \\
\hline Standart sapma & .47 & 1.48 & 7.04 & 13.15 & 5.03 & 12.02 \\
\hline
\end{tabular}

Not. Olumlu: Olumlu Mükemmeliyetçilik, Olumsuz: Olumsuz Mükemmeliyetçilik, Cinsiyet değişkeni kadın= 0, erkek= 1 olarak kodlamıştır., ${ }^{*} p<.05, * * p<.001$, Değişkenlerin kendi karşıllıları Cronbach alpha iç tutarlılık katsayılarıdır.

Mükemmeliyetçilik alt boyutları olan olumlu mükemmeliyetçilik, olumsuz mükemmeliyetçilik, düzen alt ölçek puanları, cinsiyet ve yaş değişkenlerinin kendini sabotaj puanlarını ne derece yordadığını belirleyebilmek amacıyla çoklu regresyon analizi gerçekleştirilmiştir. Gerçekleştirilen regresyon analizlerine ilişkin değişim istatistikleri Tablo 2'de, regresyon analizi sonuçları ise Tablo 3'te sunulmuştur.

Tablo 2. Kendini sabotaj yordanan değişkenine ilişkin değişim istatistikleri

\begin{tabular}{lccccccccc}
\hline Model & $R$ & $R^{2}$ & Adj $R^{2}$ & $T S H$ & \multicolumn{3}{c}{ Değişim İstatistikleri } & \multicolumn{3}{c}{$s R^{2}$} & $\Delta F$ & $s d_{1}$ \\
\hline Model 1 & .60 & .36 & .36 & 9.64 & .36 & 67.16 & 5 \\
\hline
\end{tabular}

Not. ${ }^{*} p<.001$, TSH: Tahminin Standart Hatası, sd: Serbestlik Derecesi.

Tablo 3. Kendini sabotaj yordanan değişkenine ilişkin çoklu regresyon analizi sonuçları

\begin{tabular}{|c|c|c|c|c|c|c|}
\hline \multirow[t]{2}{*}{ Model } & & \multicolumn{2}{|c|}{ Standardize Edilmemiş Katsayılar } & \multirow{2}{*}{$\begin{array}{c}\begin{array}{c}\text { Standardize } \\
\text { Katsayılar }\end{array} \\
\beta\end{array}$} & \multirow[t]{2}{*}{$t$} & \multirow[t]{2}{*}{$p$} \\
\hline & & $B$ & SH & & & \\
\hline \multirow[t]{6}{*}{ Model 1} & (Sabit) & 93.70 & 5.86 & & & $.001 * *$ \\
\hline & Cinsiyet & .84 & .87 & .03 & .96 & .336 \\
\hline & Yaş & -.58 & .27 & -.07 & -2.11 & $.035^{*}$ \\
\hline & Olumlu Mükemmeliyetçilik & -.51 & .07 & -.30 & -7.56 & $.001^{* *}$ \\
\hline & Olumsuz Mükemmeliyetçilik & .53 & .03 & .59 & 16.45 & $.001 * *$ \\
\hline & Düzen & -.38 & .09 & -.16 & -4.18 & $.001 * *$ \\
\hline
\end{tabular}

Not. Cinsiyet değişkeni kadın= 0 , erkek= 1 olarak kodlamıştır. ${ }^{*} p<.05,{ }^{* *} p<.001$.

Yapılan çoklu regresyon analizinde, kendini sabotaj puanlarını yordayan bu modelin anlamlı olduğu görülmüştür $(F(5,592)=$ $67.12, p<.001, R=.60, R^{2}=.36, R^{2}$ adj= .36). Bu model yüksek düzeyde bir etki büyüklüğüne sahiptir. Tablo 3'te mükemmeliyetçilik alt boyutlarının, cinsiyetin ve yaşın modele yaptığı katkılar görülmektedir. Tablo 3 'te görüldüğü gibi mükemmeliyetçiliğin alt boyutlarından olumlu mükemmeliyetçilik $(\beta=-.30, t=-7.56, p<.001)$ ve düzen $(\beta=-.16, t=-4.18, p<.001)$ kendini sabotaj puanlarını negatif yönde yordamaktadır. Benzer şekilde yaş da $(\beta=-.07, t=-2.11, p<.05)$ kendini sabotaj puanlarını negatif bir şekilde yordamaktadır. Diğer taraftan, olumsuz mükemmeliyetçilik $(\beta=.53, t=16.56, p<.001)$ kendini sabotaj puanlarını pozitif yönde yordamaktadır. Son olarak cinsiyet $(\beta=.03, t=.96, p>.05)$ kendini sabotaj puanlarını anlamlı bir şekilde yordamamaktadır.

\section{TARTIŞMA VE SONUÇ}

$\mathrm{Bu}$ araştırmada üniversite öğrencilerinde cinsiyet, yaşın ve mükemmeliyetçiliğin farklı boyutları olan olumlu-olumsuz mükemmeliyetçilik düzeyleri ile düzen boyutunun, kendini sabotajı yordayıcı rolü incelenmiştir. Araştırma sonucunda olumlu mükemmeliyetçiliğin kendini sabotaj davranışıla negatif yönde ilişkili olduğu bulunmuştur. Alan yazında olumlu mükemmeliyetçilik ile kendini sabotaj kavramları arasında yapılmış herhangi bir araştırmaya ulaşılamamasına rağmen, araştırma bulguları kuramsal açıklamaları destekler niteliktedir.

Kottman ve Ashby, (2000) olumlu mükemmeliyetçilik düzeyleri yüksek bireylerin belirlediği standartlara ulaşamadığında yetersizlik duyguları hissetmek yerine daha fazla çalışmaya motive olduklarını belirtmektedir. Jones ve Berglas (1978) ise kendini sabotaja başvuran bireylerin yetersiz algılanmaktan endişe ettiği ve bu sebeple performansını engelleyen davranışlara başvurduğunu belirtmektedir. Kottman ve Ashby'nin belirttiği olumlu mükemmeliyetçilik düzeyleri yüksek bireylerin özellikleri, kendini sabotaj davranışına başvuran bireyin özellikleriyle ayrışmaktadır. Ayrıca olumlu mükemmeliyetçilik düzeyi yüksek bireylerin mükemmel olmaktan keyif almaları ve başkalarının onayını alma gibi endişelerinin olmaması (Owens ve Slade, 2008), standartlarına ulaşamadığında aşırı düzeyde kaygı yaşamadıkları ve standartlara ulaşamadığı durumlarda daha fazla çalıştıkları ve çaba gösterdikleri bildirilmiştir (Stoeber ve Otto, 2006). Kendini sabote eden bireylerin ise çabalama düzeyinin düşük olması (Rhodewalt ve Tragakis, 2002) kendini sabotaj davranışları ile olumlu mükemmeliyetçilik kişilik yapısının ayrışmasını anlamlı kılmaktadır. 
Üniversite öğrencileri üzerinde gerçekleştirilen araştırmalarda olumlu mükemmeliyetçilerin benlik saygısı düzeyinin (Ward ve Ashby, 2008), özgüvenin (Rice ve Preusser, 2002) ve öz-yeterlilik düzeyinin (Locicoro ve Ashby, 2000) yüksek olduğu sonucuna ulaşılmıştır. Ayrıca diğer araştırmalarda ustalık hedef yönelimine sahip olanların (Hanchon, 2010) ve içsel kontrol odağına sahip olanların (Periasamy ve Ashby, 2002) olumlu mükemmeliyetçilik düzeylerinin yüksek olduğu sonucuna ulaşılmıştır. Kendini sabotaj ile ilgili araştırma sonuçlarında ise benlik saygısının (Yavuzer, 2015), öz-yeterlilik ve özgüvenin (Pulford vd., 2005), içsel kontrol odağının (Stewart ve De George-Walker, 2014) ve ustalık hedef yöneliminin (Üzbe, 2013) kendini sabotaj düzeyinin negatif yordayıcıları olduğu tespit edilmiştir. Literatürdeki araştırmalar birlikte incelendiğinde olumlu mükemmeliyetçilik düzeyinin kendini sabotaj düzeyinin negatif bir yordayıcısı olması olumlu mükemmeliyetçilerin öz-yeterliliklerinin, benlik saygılarının ve özgüvenlerinin yüksek olmasıyla ilişkili olabilir.

Araştırmanın diğer bir sonucu olumsuz mükemmeliyetçiliğin kendini sabotaj davranışlarının pozitif bir yordayıcısı olduğudur. Literatürde bu araştırma bulgusunu destekler nitelikte araştırma sonuçları bulunmaktadır. Stewart ve De George-Walker (2014) Avustralyalı üniversite öğrencileri üzerinde gerçekleştirdiği araştırma sonucunda da olumsuz mükemmeliyetçiliğin kendini sabotaj düzeyinin pozitif bir yordayıcısı olduğunu tespit etmiştir. Ayrıca olumsuz mükemmeliyetçilik kişilik yapısına sahip bireylerin düşük düzey benlik saygısına (Ward ve Ashby, 2008), düşük öz yeterliliğe (Locicoro ve Ashby, 2000) ve düşük özgüvene (Rice ve Preusser, 2002) sahip olduğu tespit edilmiştir. Bu sonuçların yanında dışsal kontrol odağına (Periasamy ve Ashby, 2002) sahip olanların, olumsuz mükemmeliyetçilik düzeylerinin yüksek olduğu tespit edilmiştir. Bu araştırma bulguları olumsuz mükemmeliyetçiliğin kendini sabotaj davranışlarının pozitif yordayıcısı olduğu sonucunu anlamlı kılmaktadır. Literatürdeki bu araştırmaların bulguları ele alındığında olumsuz mükemmeliyetçi bireylerin benlik saygısının, özgüvenlerinin ve öz-yeterlilik düzeylerinin düşük olması onları kendini sabotaja davranışlarına başvurmasına neden olabilir. Araştırma bulguları literatürdeki araştırma sonuçlarıyla birlikte alandaki kuramsal açıklamalarla da uyumludur. Olumsuz mükemmeliyetçilerin başkalarının onayını alma dürtüsü olduğu, standartlarına ulaşamadığında yoğun kaygı yaşadıkları (Owens ve Slade, 2008) ve belirlediği yüksek hedeflere ulaşmak için herhangi bir çaba harcamadıkları (Stoeber ve Otto, 2006) belirtilmektedir. Diğer taraftan kendini sabotaj davranışlarına başvuran bireylerin de olumsuz değerlendirme kaygısı yaşadığı (Kinnon ve Murray, 2007), akademik ertelemeye başvurdukları (Akça, 2012) tespit edilmiştir. Ayrıca Slaney vd. (2001) olumsuz mükemmeliyetçi bireylerin hatalarına karşı toleransının olmadığını, değişen durum ve şartlara göre yorum yapamadıklarını ve bu sebeple yetersizlik, aşağılık duyguları hissettiklerini belirtmektedir. Urdan ve Midgley (2001) de kendini sabotaja başvuran bireylerin amacının yetersizlik duygularıyla baş edebilmek, özsaygı ve öz-değerini korumak oluğunu vurgulamıştır.

Kearns, Forbes, Gardiner ve Marshall (2008) kendini sabotaj davranışlarının altında mükemmeliyetçi düşüncelerin olduğunu, erişilmez yüksek standartlar belirleyen mükemmeliyetçilerin, yetersizlik duygusuyla baş edebilmek için kendini sabotaj davranışlarına başvurabileceklerini belirtmiştir. Kearns vd. kendini sabotajın temelinde erişilmesi imkânsız yüksek standartlar belirleyen mükemmeliyetçi kişilik yapısı olduğunu ifade etmiştir. Dolayısıyla Kearns vd.'in kendini sabotaj davranışlarını açıklamakta yararlandığı mükemmeliyetçilik kavramı, olumsuz mükemmeliyetçi kişilik özelliklerini belirtmektedir. Kearns vd.'in kuramsal açıklamaları araştırmanın sonuçlarıyla uyumludur.

Alanyazınında mükemmeliyetçiliğin farklı boyutları ile kendini sabotaj arasındaki ilişki incelenmiş ve mükemmeliyetçilik ile kendini sabotaj arasında pozitif yönde bir ilişki olduğu tespit edilmiştir (Karner, 2014). Sözü edilen bu araştırmada Frost vd. (1990) tarafından geliştirilen çok boyutlu mükemmeliyetçilik ölçeği kullanılmıştır. Frost vd. ise geliştirdikleri bu ölçekte mükemmeliyetçiliği performansa karşı aşırı eleştirel olunması ve yoğun bir mükemmel olma arzusu olarak ele almış ve mükemmeliyetçiliği olumsuz bir kişilik özelliği olarak değerlendirmiştir. Olumsuz değerlendirilme kaygısı ise kendini sabotaj düzeyi ile pozitif yönde ilişki içerisindedir (Kinnon ve Muray, 2007). Kendini sabotaj ve mükemmeliyetçiliğin farklı boyutları arasında pozitif ilişkinin tespit edildiği araştırmalarda mükemmeliyetçiliği olumsuz kişilik özelliği olarak değerlendiren ölçekler kullanılmış ve bu araştırmalar dolaylı olarak olumsuz mükemmeliyetçilik kişilik özellikleriyle kendini sabotaj davranışları arasında ilişki tespit edilmiştir. Literatürdeki sözü edilen araştırmaların sonuçları da bu araştırma sonuçlarıyla uyumludur.

Araştırmada mükemmeliyetçiliğin düzen boyutunun kendini sabotajın negatif bir yordayıcısı olduğu sonucuna ulaşılmıştır. Mükemmeliyetçiliğin düzen boyutuyla ilgili sınırlı sayıda araştırma mevcuttur ve ulaşılabilen alanyazınında kendini sabotaj ile mükemmeliyetçiliğin düzen boyutu arasında ilişkiyi inceleyen herhangi bir araştırmaya ulaşılamamıştır. Deary ve Chalder (2010) düzen eğilimini, olumlu mükemmeliyetçiliğin bir boyutu olarak tanımlar. Slaney vd. (2001) ise olumlu mükemmeliyetçilerin hedefledikleri yüksek standartlara erişmek için planlı ve programlı çalıştıklarını, zaman planlamasıyla hareket ettiklerini belirtir. Dolayısıyla olumlu mükemmeliyetçilik kişilik özellikleri, mükemmeliyetçiliğin düzen boyutu için de geçerli olduğu söylenebilir. Özgüngör (2003) düzenli olma eğiliminin öğrenme odaklı başarı yönelimi ile pozitif bir ilişki içinde olduğunu bulmuştur. Kendini sabotaj ve başarı yönelimleri üzerine yapılan araştırmalarda (Üzbe, 2013) öğrenme odaklı olan bireylerin kendini sabotaja daha az başvurduklarını ortaya koymuştur. Ayrıca gerçekleştirilen başka bir araştırmada (Erbaş, 2012) mükemmeliyetçiliğin düzen boyutuyla öznel iyi oluşun pozitif yönde ilişkili olduğu tespit edilirken, bir başka araştırmada (Anlı, 2011) öznel iyi oluşun kendini sabotaj ile negatif yönde ilişkili olduğu tespit edilmiştir. Sarıoğlu'nun (2011) öğretmen adayları üzerinde yaptığı araştırmada düzenli olma eğiliminde olan öğretmen adaylarının, kendini sabotaj davranışlarından olan ertelemeye daha az başvurdukları sonucuna ulaşılmıştır. Düzenli mükemmeliyetçi bireyler ile ilgili yapılan araştırmalar ve yorumlar, kendini sabotaja başvuran bireylerin özellikleriyle ayrışmaktadır. Bu durum, araştırma bulgularının literatürdeki araştırma sonuçlarıyla tutarlı olduğunu göstermektedir. $\mathrm{Bu}$ araştırmanın sonuçları mükemmeliyetçiliğin düzen boyutuyla ilgili yapılan çalışmaları desteklemektedir. Ayrıca literatürde düzen boyutunun olumlu mükemmeliyetçilikle ilişkilendirilmesi, araştırma sonucunda olumlu mükemmeliyetçiliğin kendini 
sabotajın negatif yordayıcı olması sonucuyla birlikte değerlendirildiğinde, araştırma sonuçlarının kendi içinde tutarlı olduğu söylenebilir.

Araştırma sonucunda üniversite öğrencilerinde cinsiyetin kendini sabotaj düzeyinin anlamlı bir yordayıcıSı olmadığı tespit edilmiştir. Alanda bu sonucu destekleyen araştırmalar (Elmas ve Akfırat 2015; Kalyon, Dadandı ve Yazıcı, 2016; Kinnon ve Murray, 2007; Sarıçalı, 2014; Üzbe, 2013) bulunmaktadır. Ancak, Brown vd. (2012), Hirt vd. (2000), Kimble ve Hirt (2005), Mccrea vd. (2008), Anlı (2011) erkeklerin daha fazla kendini sabotaja başvurduklarını, Pulford vd. (2005) ve Yavuzer (2015) ise kadınların daha fazla kendini sabotaja başvurduklarını tespit etmiştir.

Araştırma sonucunda yaşın kendini sabotajın negatif bir yordayıcısı olduğu sonucuna ulaşılmıştır. Araştırmanın bu sonucu alandaki diğer araştırmalarla uyumludur. Türk üniversite öğrencilerinde kendini sabotaj ve yaş arasındaki ilişkiyi inceleyen araştırma bulunmamasına rağmen kendini sabotaj düzeyi ile ilişkili öz-yeterlilik (Oğuz, 2009) ve öğrenmeye yeteneğine yönelik inanç (Alemdağ, 2015) ile yaş arasındaki ilişkiyi inceleyen araştırmalar bulunmaktadır. Mevcut araştırmalar (Oğuz, 2009; Alemdağ, 2015) sonucunda Türk üniversite öğrencilerinde yaşın artmasıyla birlikte öz-yeterlilik düzeylerinin arttığı ve yaşın artmasıyla öğrencilerin öğrenme yeteneğinin geliştirilebilir bir özellik olduğuna yönelik inançlarında artış olduğu tespit edilmiştir. Öz-yeterlilik (Pulford vd., 2005) ve yeteneklerin değişmeyeceğine yönelik inancın (Rhodewalt ve Tragakis, 2002) kendini sabotajı negatif yordadığı bilinmektedir. Bu doğrultuda Türk üniversite öğrencilerinin yaşlarının artmasıyla birlikte kendini sabotaj eğilimlerinin azalacağı söylenebilir.

Alan yazında bu araştırma sonucuyla farklılık gösteren araştırma da (Litvinova vd., 2015) mevcuttur. Ancak bu araştırma güney batı Afrika bölgesinde gerçekleştirilmiştir ve kendini sabotaj düzeyini etkileyen değişkenler kültürlere göre farklılık gösterebilir. Ülkemizde ise Zafer (2016) tarafından yaşları 20 ile 40 arasında değişen itfaiye çalışanları üzerinde gerçekleştirilmiş araştırma sonucunda kendini sabotaj ve yaş arasında herhangi bir ilişki tespit edilememiştir. Zafer araştırmasını yaşları 20 ile 40 arasında değişen bir grupla gerçekleştirmiştir. Araştırma örnekleminin çalışan bireylerden oluşması ve performanslarıyla ilgili çevresinin beklentisinin olmaması ve yeterliliklerinin yoğun bir şekilde sınanmaması kendini sabotaj düzeylerini tespit etmeyi güçleştirmiş olabilir. Bu araştırmanın örneklemi olan üniversite öğrencileri sürekli olarak sınavlara girmekte ve yeterlilikleri sürekli olarak incelenmektedir. Bu durum üniversite öğrencilerinin yaşam tarzında kendini sabotaj davranışlarını seçenek olarak görmelerine neden olabilir ve kendini sabotaj davranışlarına yönelme veya uzaklaşma eğilimleri daha belirgin tespit edilebilir. Bireylerin yaşlarının artması benlik imajlarını korumak için performans engelleyici stratejilere başvurmalarını engellemeyebilir. Alan yazındaki farklı çalışma sonuçları ve bu konuda yapılmış sınırlı sayıda araştırma kendini sabotaj ve yaş arasındaki ilişkiyi incelemek için daha fazla çalışmaya ihtiyaç olduğunu göstermektedir.

$\mathrm{Bu}$ araştırmanın bazı sınırlılıkları bulunmaktadır. İlk sınılılık araştırma örneklemiyle ilgilidir. Bu araştırmada araştırma örneklemini eğitim fakültesi öğrencileri oluşturmuştur. Eğitim fakültesi öğrencileri cinsiyet ve yaş gibi bazı noktalarda diğer fakültelerdeki öğrencilerle benzerlik göstermelerine rağmen, öğrencilerin sosyoekonomik düzeyi ve kişilik özellikleri gibi öğrencilerle ilgili diğer faktörler fakülteler arasında farklılık gösterebilir. Bu nedenle, araştırma sonuçlarının diğer fakültelerde öğrenim gören öğrenciler için genellenebilirliği düşüktür. Bu araştırmanın ikinci sınırlılığı, bu araştırmada kesitsel bir araştırma deseni kullanılmasıdır. Kesitsel araştırma desenlerinde bulgular arasında neden sonuç ilişkisi kurulamaz. Bu araştırmanın üçüncü ve son sınırlılı̆ı veri toplama türüyle ilgilidir. Bu araştırmada araştırma verileri öz-bildirim tarzı ölçekler aracılığıyla toplanmıştır. Öz bildirim tarzı ölçeklere orta yol cevap verme, sosyal beğenilirlik gibi bazı hataların karışma olasılığı yüksektir. Her ne kadar bu hataları en aza indirmek için öğrencilerin anketi kimlik bilgilerini bildirmeden cevaplamaları sağlanmış olsa da araştırma sonuçları öz-bildirim tarzı ölçeklerin kullanılmasından kaynaklanan sınırlııkları içermektedir.

Sonuç olarak bu araştırma sonucunda, olumlu mükemmeliyetçilik düzeyinin ve yaşın artmasının kendini sabotaj düzeyinin negatif bir yordayıcısı olduğu, olumsuz mükemmeliyetçilik düzeyinin ise kendini sabotaj düzeyinin pozitif bir yordayıcısı olduğu sonucuna ulaşılmıştır. Ayrıca mükemmeliyetçiliğin düzen boyutunun kendini sabotajın negatif bir yordayıcısı olduğu sonucuna ulaşıırken, cinsiyetin kendini sabotajın anlamlı bir yordayıcısı olmadığı sonucuna ulaşılmıştır. Kendini sabotaj davranışlarının azaltılmasının hedeflendiği psikoeğitim programlarının tasarlanmasında katılımcılarının gelişim düzeyinin dikkate alınması ve mükemmeliyetçilik kavramının olumsuz mükemmeliyetçilik ve düzen boyutlarına odaklanılması programların etkililiğinin artırılmasına yardımcı olabilir.

\section{KAYNAKÇA}

Abacı, R. ve Akın, A. (2011). Kendini sabotaj insanoğlunun sınırlı doğasının bir sonucu. Ankara: Pegem Akademi Yayıncılık.

Akça, F. (2012). An investigation into the self-handicapping behaviors of undergraduates in terms of academic procrastination, the locus of control and academic success. Journal of Education and Learning, 1(2), 288-297.

Akın, A. (2012). Kendini sabotaj ölçeği: Geçerlik ve güvenirlik çalışması. Eğitim ve Bilim, 37(164), 164-187.

Alemdağ, C. (2015). Beden eğitimi öğretmeni adaylarının epistemolojik inançları, akademik öz-yeterlikleri ve öğrenme yaklaşımları. (Yayımlanmamış doktora tezi). Karadeniz Teknik Üniversitesi, Trabzon.

Altun, F. ve Yazıcı, H. (2010). Öğrencilerin olumlu ve olumsuz mükemmeliyetçilik özellikleri ile akademik başarıları arasındaki ilişkiler. International Conference on New Trends in Education and Their Implications, 11, 534-539.

Anlı, G. (2011). Kendini sabotaj ve psikolojik iyi olma arasındaki ilişkinin çeşitli değişkenler açısından incelenmesi. (Yayımlanmamış yüksek lisans tezi). Sakarya Üniversitesi, Sakarya. 
Ashby, J. S. ve Kottman, T. (1996). Inferiority as a distinction between normal and neurotic perfectionism. Individual Psychology, 52(3), 238-245.

Ashby, J. S. ve Rice, K. G. (2002). Perfectionism, dysfunctional attitudes, and self-esteem: A structural equations analysis. Journal of Counselling and Development, 80(2), 197-203.

Baumeister, R. F. (1997). Esteem threat, self-regulatory breakdown, and emotional distress as factors in self-defeating behavior. Review of General Psychology, 1(2), 145-174.

Beck, B., Koons, S. ve Milgrim, D. (2001). Correlates and consequences of behavioral procrastination: The effects of academic procrastination, self-consciousness, self-esteem, and self-handicapping. Journal of Social Behavior and Personality, 16(1), 3-13.

Berglas, S. ve Jones, E. E. (1978). Drug choice as a self-handicapping strategy in response to noncontingent success. Journal of Personality and Social Psychology, 36(4), 405.

Brown, C. M., Park, S. W. ve Folger, S. F. (2012). Growth motivation as a moderator of behavioral self-handicapping in women. The Journal of Social Psychology, 152(2), 136-146.

Burka, J. B. ve Yuen, L. M. (2008). Procrastination: Why you do it, what to do about it now. Cambridge: Da Capo Press.

Burns, D. D. (1980). Feeling good: The new mood therapy. New York: The New American Library Inc.

Coşar, S. (2012). Çalışanların tükenmişlik düzeyleri ile kendini engelleme düzeyleri arasındaki ilişkinin incelenmesi. (Yayımlanmamış yüksek lisans tezi). Maltepe Üniversitesi, İstanbul.

Damjan, S. ve Darja, K. G. (2011). Competitiveness and motivation for education in self-handicapping. Studia Psychologica, 53(1), 83-96.

Deary, V. ve Chalder, T. (2010). Personality and perfectionism in chronic fatigue syndrome: A closer look. Psychology and Health, 25(4), 465-475.

Elliot, A. J. ve Church, M. A. (2003). A motivational analysis of defensive pessimism and self-handicapping. Journal of Personality, 71(3), 369-396.

Elmas, P. ve Akfırat, S. (2015). Mazeret bulma eğilimi ile özsaygı arasındaki ilişkinin incelenmesi: mazeret bulma eğilimi başarısızlık durumunda özsaygıyı korur mu? Başlangıçtaki özsaygı düzeyinin rolü. Psikoloji Çalışmaları Dergisi, 34(2), 17-34.

Enders, C. K. (2010). Applied missing data analysis. New York: Guilford Press.

Erbaş, M. (2012). Öğretmen adaylarının mükemmeliyetçilik düzeylerinin red duyarlılığı ve öznel iyi oluş düzeylerine göre incelenmesi. (Yayımlanmamış yüksek lisans tezi). Ondokuz Mayıs Üniversitesi, Samsun.

Flett, G. L. ve Hewitt, P. L. (2002). Perfectionism and maladjustment: An overview of theoretical, definitional, and treatment issues. Flett, G. L. ve Hewitt, P. L. (Ed.), Perfectionism: Theory, research, and treatment, içinde (ss. 5-31). Washington: American Psychological Association.

Frost, R. O., Marten, P. A., Lahart, C. ve Rosenblate, R. (1990). The dimensions of perfectionism. Cognitive Therapy and Research, 14(4), 449-468.

Geçtan, E. (2002). Psikanaliz ve sonrası. İstanbul: Mentis Yayıncılık.

Graham, J. W. (2009). Missing data analysis: Making it work in the real world. Annual Review of Psychology, 60(1), 549-576 doi:10.1146/annurev.psych.58.110405.085530.

Greaven, S. H., Santor, D. A., Thompson, R. ve Zuroff, D. C. (2000). Adolescent self-handicapping, depressive affect, and maternal parenting style. Journal of Youth and Adolescence, 29, 631-646.

Hamachek, D. E. (1978). Psychodynamics of normal and neurotic perfectionism. Psychology: A Journal of Human Behavior, 15(1), 27-33.

Hendrix, K. S. ve Hirt, E. R. (2009). Stressed out over possible failure: The role of regulatory fit on claimed self-handicapping. Journal of Experimental Social Psychology, 45, 51-59.

Hirt, E. R., Mccrea, S. M. ve Boris, H. I. (2003). I know you self-handicapped last exam: Gender differences in reactions to self-handicapping. Journal of Personality and Social Psychology, 84(1), 177-193.doi: 10.1037/0022-3514.84.1.177.

Hirt, E. R., McCrea, S. M. ve Kimble, C. E. (2000). Public self-focus and sex differences in behavioral self-handicapping: Does increasing self-threat still make it "just a man's game?". Personality and Social Psychology Bulletin, 26(9), 1131-1141.

Hollender, M. H. (1965). Perfectionism. Comprehensive Psychiatry, 6(2), 94-103.

Jones, E. E. ve Berglas, S. (1978). Control of attributions about the self through self-handicapping strategies: The appeal of alcohol and the role of underachievement. Personality and Social Psychology Bulletin, 4(2), 200-206.

Jones, E. E. ve Rhodewalt, F. (1982). The self-handicapping scale. Princeton, NJ: Princeton University.

Kalyon, A., Dadandı, I. ve Yazıcı, H. (2016). Kendini sabote etme eğilimi ile narsistik kişilik özellikleri. Düşünen Adam, 29(3), 237-246. doi: 10.5350/DAJPN2016290305.

Karner, A. (2014). Perfectionism and self-handicapping in adult education. Procedia-Social and Behavioral Sciences, 142, 434-438. doi: 10.1016/j.sbspro.2014.07.699.

Kearns, H., Forbes, A., Gardiner, M. ve Marshall, K. (2008). When a high distinction isn't good enough: A review of perfectionism and selfhandicapping. Australian Educational Researcher, 35(3), 21-36.

Kıral, E. (2012). Ilköğretim okulu yöneticilerinin mükemmeliyetçilik algısı ve kontrol odağı ile ilişkisi. (Yayımlanmamış doktora tezi). Ankara Üniversitesi, Ankara.

Kimble, C. E. ve Hirt, E. R. (2005). Self-focus, gender, and habitual self-handicapping: Do they make a difference in behavioral selfhandicapping?. Social Behavior and Personality: An international journal, 33(1), 43-56.

Kinnon, M. C. ve Murray, C. B. (2007). A profile of college self-handicapper. Undergraduate Research Journal, 1, 13-17.

Kottman, T. ve Ashby, J. (2000). Perfectionistic children and adolescents: Implications for school counselors. Professional School Counseling, 3(3), 182-188.

Krejcie, R. V. ve Morgan, D. W. (1970). Determining sample size for research activities. Educational and Psychological Measurement, 30(3), 607610.

| Kastamonu Eğitim Dergisi, 2020, Vol. 28, No. 3| 
Leary, M. R. ve Shepperd, J. A. (1986). Behavioral self-handicaps versus self-reported handicaps: A conceptual note. Journal of Personality and Social Psychology, 51(6), 1265-1268. doi:10.1037/0022-3514.51.6.1265

Leondari, A. ve Gonida, E. (2007). Predicting academic self-handicapping in different age groups: The role of personal achievement goals and social goals. British Journal of Educational Psychology, 77(3), 595-611.

Little, R. J. (1988). A test of missing completely at random for multivariate data with missing values. Journal of the American Statistical Association, 83(404), 1198-1202. doi:10.1080/01621459.1988.10478722.

Litvinova, A., Balarabe, M. ve Mohammed, A. I. (2015). Influence of personality traits and age on academic self-handicapping among undergraduate students of Ahmadu Bello University, Zaria, Nigeria. Psychology, 6(15), 1995-2003.doi: 10.4236/psych.2015.615197.

Locicero, K. A. ve Ashby, J. S. (2000). Multidimensional perfectionism and self-reported self-efficacy in college students. Journal of College Student Psychotherapy, 15(2), 47-56.

Mccrea, S. M., Hirt, E. R. ve Milner, B. J. (2008). She works hard for the money: Valuing effort underlies gender differences in behavioral selfhandicapping. Journal of Experimental Social Psychology, 44(2), 292-311. doi:10.1016/j.jesp.2007.05.006.

Mello-Goldner, D. ve Jackson, J. (1999). Premenstrual syndrome (PMS) as a self-handicapping strategy among college women. Journal of Social Behavior and Personality, 14(4), 657-669.

Oğuz, A. (2009). Sınıf öğretmeni adaylarının akademik öz-yeterlik inançlarının incelenmesi. Anadolu Üniversitesi Eğitim Bilimleri Enstitüsü Dergisi, 2(2), 15-29.

Owens, R. G. ve Slade, P. D. (2008). So perfect it's positively harmful? Reflections on the adaptiveness and maladaptiveness of positive and negative perfectionism. Behavior Modification, 32(6), 928-937.

Özçetin, Y. S. Ü. ve Hiçdurmaz, D. (2016). Kendini sabote etme ve ruh sağlığı üzerine etkisi. Psikiyatride Güncel Yaklaşımlar, 8(2), 145-154. doi: $10.18863 /$ pgy.13806.

Özgüngör, S. (2003). Mükemmeliyetçilik ve özerklik destekleyici davranışların amaç tarzları ile ilişkisi. Eğitim ve Bilim, 28(127), 25-30.

Periasamy, S. ve Ashby, J. S. (2002). Multidimensional perfectionism and locus of control: Adaptive vs maladaptive perfectionism. Journal of College Student Psychotherapy, 17(2), 75-86.

Pulford, B. D., Johnson, A. ve Awaida, M. (2005). A cross-cultural study of predictors of self-handicapping in university students. Personality and Individual Differences, 39(4), 727-737. doi:10.1016/j.paid.2005.02.008.

Rhodewalt, F. ve Tragakis, M. (2002). Self-handicapping and the social self: The cost and rewards of interpersonal self-construction. New York: Psychology Press.

Rice, K. G. ve Preusser, K. J. (2002). The adaptive-maladaptive perfectionism scale. Measurement and Evaluation in Counseling and Development, $34(4), 210-222$

Roedell, W. C. (1984). Vulnerabilities of highly gifted children. Roeper Review, 3(6), 127-130.

Sahranç, Ü. (2011). An investigation of the relationships between self-handicapping and depression, anxiety, and stress. International Online Journal of Educational Sciences, 3(2), 526-540.

Sapmaz, F. (2006). Üniversite öğrencilerinin uyumlu ve uyumsuz mükemmeliyetçilik özelliklerinin psikolojik belirti düzeyleri açısından incelenmesi. (Yayımlanmamış yüksek lisans tezi), Sakarya Üniversitesi Sosyal Bilimler Enstitüsü, Sakarya.

Sarıçalı, M. (2014). Psikolojik danışman adaylarının kendini engelleme algılarının özgünlük düzeyleri ve aldıkları süpervizyon açısından incelenmesi. (Yayımlanmamış yüksek lisans tezi). Anadolu Üniversitesi, Eskişehir.

Sarığlu, A. F. (2011). Öğretmen adaylarının akademik erteleme eğilimi ile mükemmeliyetçilik düzeyleri arasındaki ilişkinin incelenmesi. (Yayımlanmamış yüksek lisans tezi). İstanbul Üniversitesi, İstanbul.

Schafer, J. L. ve Graham, J. W. (2002). Missing data: Our view of the state of the art. Psychological Methods, 7(2), 147-177. doi:10.1037/1082989X.7.2.147.

Slade, P. D. ve Owens, R. G. (1998). A dual process model of perfectionism based on reinforcement theory. Behavior Modification, 22(3), 372390.

Slaney, R. B. ve Ashby, J. (1996). Perfectionists: Study of a criterion group. Journal of Counselling and Development,74(4), 393-398.

Slaney, R. B., Rice, K. G., Mobley, M., Trippi, J. ve Ashby, J. S. (2001). The revised almost perfect scale. Measurement and Evaluation in Counseling and Development, 34(3), 130-145.

Smederevac, S., Novovic, Z., Milin, P., Janicic, B., Pajic, D. ve Biro, M. (2003). Tendency to self-handicapping in the situation of expected failure. Psihologija, 36(1-2), 39-58.

Smith, T. W. Snyder, C.R. ve Perkins, S. C. (1983). The self-serving function of hypochondriacal complaints: Physical symptoms as selfhandicapping strategies. Journal of Personality and Social Psychology, 40(4), 787-797. doi:10.1037/0022-3514.44.4.787

Stewart, M. A. ve De George-Walker, L. (2014). Self-handicapping, perfectionism, locus of control and self-efficacy: A path model. Personality and Individual Differences, 66, 160-164.

Stoeber, J. ve Otto, K. (2006). Positive conceptions of perfectionism: Approaches, evidence, challenges. Personality and Social Psychology Review, 10(4), 295-319.

Suddarth B. H. ve Slaney R.B. (2001). An investigation of the dimensions of perfectionism in college students. Measurement Evaluation in Counseling and Development, 34, 157-165.

Tabachnick, B. G. ve Fidell, L. S. (2012). Using multivariate statistics (6. bs.). Harlow, Essex: Pearson Education.

Ulu, i. P. (2007). An investigation of adaptive and maladaptive dimensions of perfectionism in relation to adult attachment and big five personality traits. (Yayımlanmamış doktora tezi). Ortadoğu Teknik Üniversitesi, Ankara. 
Urdan, T. ve Midgley, C. (2001). Academic self-handicapping: What we know, what more there is to learn? Educational Psychology Review, 13(2), 115-138.

Üzbe, N. (2013). Başarı hedef yönelimi, benlik saygısı ve akademik başarının kendini engellemeyi yordamadaki rolü. (Yayımlanmamış yüksek lisans tezi). Gazi Üniversitesi, Ankara.

Want, J. ve Kleitman, S. (2006). Imposter phenomenon and self-handicapping: Links with parenting styles and self-confidence. Personality and Individual Differences, 40(1), 961-971. doi:10.1016/j.paid.2005.10.005.

Ward, A. M. ve Ashby, J. S. (2008). Multidimensional perfectionism and the self. Journal of College Student Psychotherapy, 22(4), 51-65.

Yavuzer, Y. (2015). Investigating the relationship between self-handicapping tendencies, self-esteem and cognitive distortions. Educational Sciences: Theory and Practice, 879-890. doi:10.12738/estp.2015.4.2434.

Zafer, M. (2016). Itfaiye çalışanlarında psikolojik dayanıklılı ve kendini sabotaj düzeylerinin incelenmesi: istanbul itfaiyesi örneği. (Yayımlanmamış yüksek lisans tezi). Nişantaşı Üniversitesi, İstanbul.

Zuckerman, M., Kieffer, S. C. ve Knee, C. R. (1998). Consequences of self-handicapping: Effects on coping, academic performance and adjustment. Journal of Personality and Social Psychology, 74(6), 1619-1628. 